INTERNATIONAL JOURNAL OF RESEARCH IN SOCIAL SCIENCES \& HUMANITIES

An International Open-Access Peer Reviewed Referred Journal

\title{
FUNCTIONAL LOAD AND PRONUNCIATION INSTRUCTION IN THE IRAQI EFL CONTEXT
}

\section{Dr. Majid Rasim Younus}

University of Baghdad, College of Education Ibn Rushd for Human Sciences, Iraq DOI: http://doi.org/10.37648/ijrssh.v12i01.024

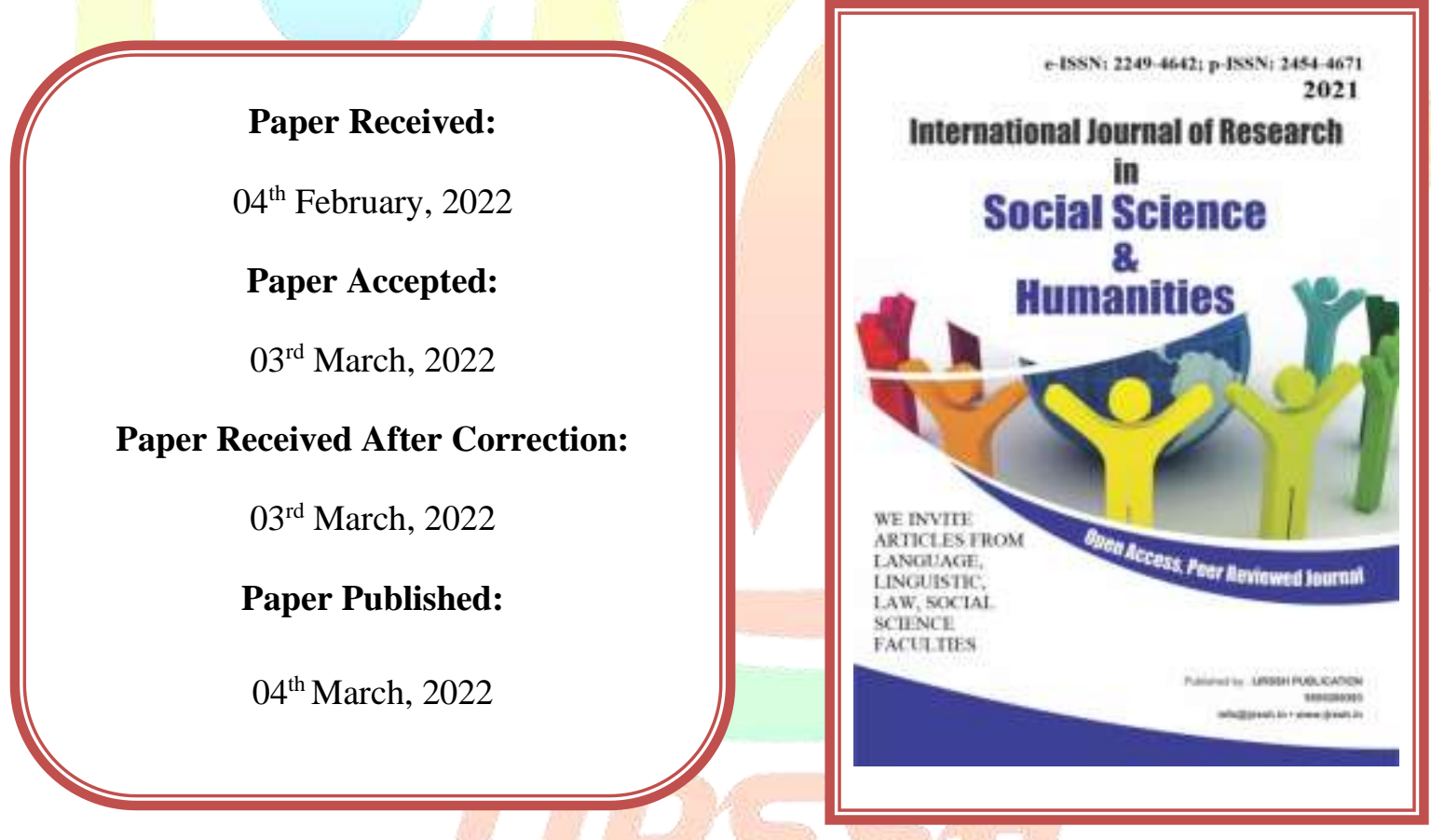

How to cite the article: Younus M.R. (2022), Functional Load and Pronunciation Instruction in the Iraqi EFL Context, January-March 2022 Vol 12, Issue 1; 489-502 DOI: http://doi.org/10.37648/ijrssh.v12i01.024 


\begin{abstract}
Though it is crucial for the development of ESL / EFL learners' speech perception and production, pronunciation is almost neglected in the English textbooks used at Iraqi schools. This negligence is both in terms of content and instruction. In such textbooks, very little pronunciation materials can be found and very limited time for practice is available for the teacher. This article aims to overcome the above shortcoming of English textbooks at Iraqi schools by setting priorities in English pronunciation based on the Functional Load principle. For this aim, an investigation is carried out following a qualitative methodology. The qualitative results have identified a set of phonemic priorities for the teaching of English pronunciation in Iraqi schools. These priorities represent high and low phonemic loads which can enrich the English textbooks in Iraqi schools and guide in some way the teaching of pronunciation.
\end{abstract}

Key Words: Functional load, Pronunciation priorities, Phonemic conflations, Qualitative

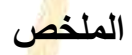

على الرغم من أهميتها في تطوير إدراك و إنتاج طلاب اللغة الإنجليزية كلغة ثانية الا ان النطق مهملا الكتب المدرسية الإنجليزية المستخدمة في المدارس العر اقية. هذا الإهمال هو من حيث المحتوى و التدريب. في مثل هذه الكتب المدرسية ،

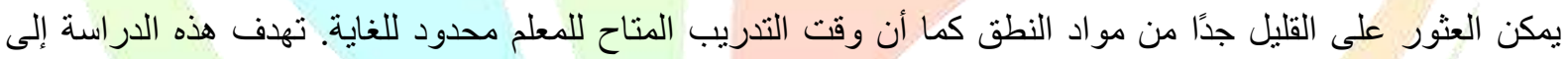
التغلب على النقص المذكور أعلاه في كتب اللغة الإنجليزية في المدارس العراقية من خلال تحديد الأولويات في النطق باللغة الإنجليزية على أساس مبدأ التقل الوظيفي. لهذا الهدف، نم إجراء تحقيقي باتباع منهجية وصفية. وقد حددت النتائج الوصفية مجموعة من الأولويات الصوتية لتدريس نطق اللغة الإنجليزية في المدارس العر اقية. تمثل هذه الأولويات اثقال صوتية عالية ومنخفضة. بما يمكن المعنيين إثراء كتب اللغة الإنجليزية في الددارس العراقية وتوجيه تدريس النطق بطريقة ما.

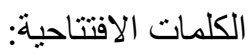
الثقل الوضيفي, تعليم النطق , اللغة الانجليزية كلغة اجنبية 


\section{INTRODUCTION}

Most cited works on English pronunciation in EFL/ESL contexts pointed out two contradictory viewpoints regarding the teaching of pronunciation: marginalized and/or prioritized. In this respect, Levis (2018, p.1) stated that "there was no in-between. Either pronunciation was still important, or it largely disappeared from language-teacher training." In the Iraq EFL context, pronunciation status reflects its subservient role to other language skills like speaking and listening. This minor role of pronunciation is reflected in the materials of the English textbooks prescribed for schools by the Iraqi Ministry of Education. In these textbooks, almost nothing is given for pronunciation as for content and instruction. Also, the teacher has no clues of what pronunciation content to include and how to teach it (Amin, 2017; Altufail, 2016). Such a decision is left to the English language teacher's intuition. This shortcoming of English textbooks for Iraqi schools regarding pronunciation deserves serious investigation and prompt remedy. The present article aims at identifying the types of phonemic conflations of high communicative value found in the speech of Iraqi EFL school pupils. By identifying such phonemes, their content and instruction can be included in the English textbooks at Iraqi schools for successful speech perception and production outcomes. For this aim, Brown's (1988) model of Functional Load (FL) will be used to identify and prioritize the phonemic contrasts found in the speech of Iraqi intermediate school pupils / Alrisafah-3. To pursue this aim, the following research questions are formulated:

1. What are the phonemic contrasts found in the speech of Iraqi intermediate school pupils?

2. How are these phonemic contrasts prioritized for pronunciation teaching purposes?

\section{THE STATUS OF ENGLISH PRONUNCIATION}

Pronunciation refers to the production and perception of the sound system of a language, segmental and supra-segmental (Nunan, 2003, p.113). The sound system of a language, both phonemics and prosody, influences meanings in two ways: differentiation and contribution. The segmental phonemes differentiate meanings among words, whereas the supra segmental phonemes add extra meanings to a group of words, 
denotative and connotative respectively. In this respect, Burgess and Spencer (2000, p.191) wrote that "pronunciation in language learning, on the other hand, is the practice and meaningful use of the target language phonological features in speaking, supported by practice in interpreting those phonological features in a target language discourse that one hears."

Despite the important role given to pronunciation for oral communication, the status of English pronunciation in the Iraqi schools is currently of a subsidiary role (Abid, 2012). Based on the related literature, the status of English pronunciation in Iraqi schools went through three phases: entirely neglected, highly prioritized and marginalized.

The first phase was characterised by the absence of pronunciation content and practice. In this period, all English textbooks followed the Grammar Translation Method (GTM) whose aim was to develop the reading and writing skills. In the GTM, the emphasis was placed on the memorization (of vocabulary and grammar) and on translation. In this phase, the choice of pronunciation content and practice was left to the school teachers' intuition (Abdul-Kareem, 2009, p.9).

The second phase which accompanied the rise of Behaviorism and
Structuralism placed much emphasis on pronunciation content and instruction (Amin, 2017). As a theory of learning, behaviourism emphasized constant repetition and reinforcement. As a theory of language, structuralism emphasized the analysis of language into linguistic units. In this respect, de Bot et al. (2005, p.77) mentioned that "structuralist linguistics provided tools for analyzing language into chunks and behavioural theory provided a model for teaching any behaviour by conditioning." In this second phase, the Audio Lingual Method (ALM) was the most dominant English language teaching method. According to the ALM, a typical pronunciation class emphasized constant practice and explicit instructions. Murphy (2003, p.113) describes pronunciation instructions as "based upon scripts and dialogues to be memorised, language lessons feature teacher-led presentations of language samples, substitution drills, intensive practice with sentence patterns, and so forth." In Iraq, the teaching of pronunciation coincided with the use of the locally produced series of English textbooks for schools entitled the 'New English Course for Iraq' (see, Altufaili, 2016). Commenting on this series, Amin (2017, p.579) wrote that "it was designed on the structural approach and a new 
method of teaching, the Audio-lingual Method, was recommended for teaching this programme."

The third phase was associated with the emergence of the Communicative Language Teaching (CLT). The status of pronunciation within the CLT went through two stages. It was marginalized at the beginning as a reaction against the ALM and its insistence on achieving perfection in pronunciation through repetition drills. Researchers with a CLT standpoint considered ALM set goals for pronunciation fruitless and unrealistic because no one except native English speakers will acquire perfection in pronunciation. The second stage of the CLT as proposed by Levis (2018) regarded pronunciation a crucial element of oral communication. Since communication is the goal, the teaching of pronunciation should focus on those aspects which have communicative values. In this regard, linking pronunciation with communication have led to the renewed interest in the principle of Functional Load by Brown (1988) and intelligibility by Abercrombie (1949). This article adopts Brown model of prioritizing pronunciation for the purpose of communication. The next section introduces priorities of pronunciation and states the justification for using Brown's (1988) model.

\section{SETTING \\ PRONUNCIATION PRIORITIES}

Influenced by the communicative function of language, many researchers were occupied with establishing pronunciation priorities of communicative values. The quest was to identify and prioritize these features for the purpose of teaching pronunciation. In this regard, three main orientations of research were identified. The first research orientation was initiated by Brown (1988) who proposed the Functional Load principle which was to measure the number of minimal pairs a certain phonemic contrast distinguishes (Brown, 1988, p.594). The term FL was also defined by Gilner and Morales (2010, p.136) as "a means of quantifying the relative amount of work elements from a linguistic class do in the language.

The above definitions mark FL a completely distinct phonological unit from previous interpretations of the phoneme concept. Moreover, FL means that the difficulty of the sound system of a target language is no longer determined, for the purpose of teaching, on contrastive and error analysis approaches. What makes a sound worthy of teaching is its 
communicative importance in distinguishing many lexical units (Brown, 1988; Levis, 2018). As far as setting pronunciation priorities is concerned, Brown (1988) was interested in analyzing EFL learners' pronunciation errors in terms of their effect on distinguishing many words. Thus, he classified the ESL/EFL learners' pronunciation errors into high FL and low FL based on a hierarchical scale from 10, very high, to 1 , very low. Table (1) is a list suggested by Brown (1988) of phonemic contrast of high FL and Low FL.

Table (1): Functional Loads of Phonemes (Brown, 1988)

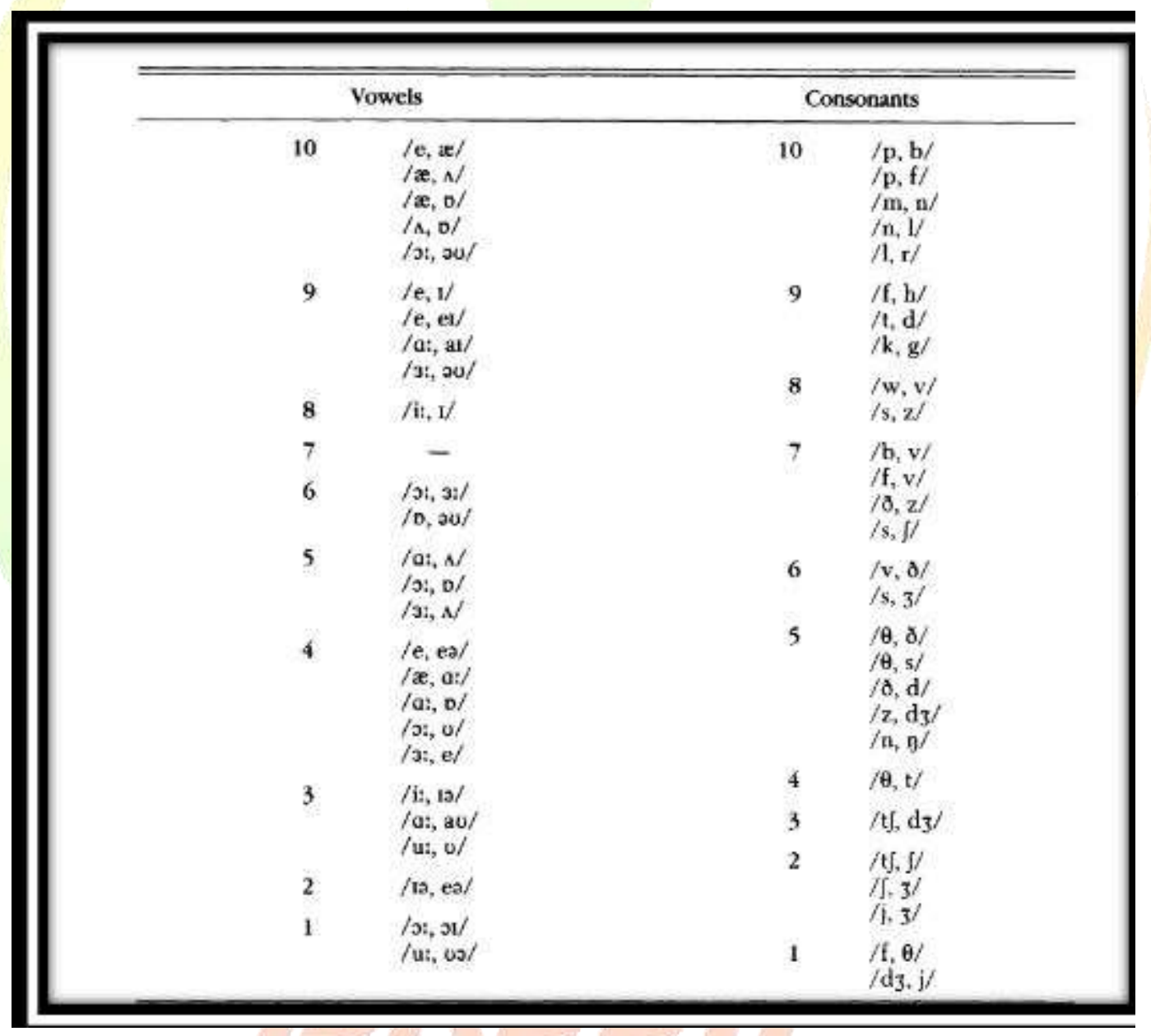

The second research orientation on prioritising pronunciation is Jenkins' (2000) study. Jenkins (2000) suggested a pronunciation model based on core and non-core features for the use of English as an international language (EIL). This proposed Lingua Franca Core 
pronunciation is "a revised pronunciation syllabus which targets for production those features of GA and RP which were found to be crucial in promoting intelligible pronunciation in ELF interactions" (Jenkins, 2006, p.76). Jenkins' (2000) study relied on recorded materials involving advanced EFL learners of English. Based on these materials and the meaning negotiations among the interlocutors, the core and non-core features were determined. Table (2) represents Jenkins' (2000) pronunciation model.

Table (2) : Jenkins (2005, cited in Zoghbor, 2011:54)

\begin{tabular}{|c|c|c|}
\hline$f$ & EFL Targets & ELF Targets \\
\hline \multirow{3}{*}{ Consonant inventory } & All phonemes & All phonemes except for $/ \theta /$ and $/ ð /$ \\
\hline & $\begin{array}{l}\text { RP non-rhotic } / \mathrm{r} / \\
\text { GA rhotic } / \mathrm{r} /\end{array}$ & Rhotic /r/ only \\
\hline & $\begin{array}{cc}\mathrm{RP} & \text { intervocalic } \\
& {[\mathrm{t}]} \\
\mathrm{GA} & \text { intervocalic } \\
& {[\mathrm{t}]}\end{array}$ & Intervocalic $[\mathrm{t}]$ only \\
\hline Phonetic requirements & Rarely specified & $\begin{array}{l}\text { Aspiration after } / \mathrm{p} /, / \mathrm{t} / \text {, and } / \mathrm{k} / \text {. Appropriate vowel length before } \\
\text { fortis/lenis consonant phonemes. }\end{array}$ \\
\hline Consonant cluster & $\begin{array}{ll}\text { All } & \begin{array}{l}\text { word } \\
\text { positio } \\
\text { ns }\end{array} \\
\end{array}$ & Word initially, word medially \\
\hline Vowel quantity & $\begin{array}{l}\text { Long-short } \\
\text { contras } \\
\mathrm{t}\end{array}$ & Long-short contrast \\
\hline Vowel quality & $\begin{array}{c}\text { Close to RP or } \\
\text { GA }\end{array}$ & $\begin{array}{l}\text { L2 (consistent) regional qualities. } \\
\text { Plus } / 3: / .\end{array}$ \\
\hline Weak forms & Essential & Unhelpful to intelligibility \\
\hline $\begin{array}{l}\text { Features of connected } \\
\text { speech }\end{array}$ & All & Inconsequential or unhelpful \\
\hline Stress-timed rhythm & Important & Does not exist \\
\hline Word stress & Critical & Unnecessary / can reduce flexibility \\
\hline Nuclear (tonic) stress & Important & Critical \\
\hline
\end{tabular}

The third research orientation is Gimson's (2001) Minimum General Intelligibility. Gimson (2001) proposed modifying the sound system of RP to include alternative features from other native English varieties like GA. The main motive for GImson's approach is to ensure mutual understanding and lessen the negative effect caused by phonemic variations among native English varieties. For this to accomplished, it requires "that the context is 
known, and the listener can tune in to the foreign accent" (Gimson, 2001, p.298). Table (3) is a summary of the model compared to the RP model.

Table (3) : Gimson's (2001) Minimum General Intelligibility

\begin{tabular}{|c|c|c|c|}
\hline $\mathbf{R P}$ & MGI & $\mathbf{R P}$ & MGI \\
\hline /i:/ & as RP & /eI/ & [e:] \\
\hline$/ \mathrm{I} /$ & as RP & $/ \partial \sigma /$ & {$[0:]$} \\
\hline /e/ & {$[\varepsilon]$} & $/ \mathrm{aI} /$ & as $\mathrm{RP}$ \\
\hline$/ æ /$ & [a] & $/ a v /$ & as RP \\
\hline /a:/ & /a:/ or /a:r/ & /OI/ & as RP \\
\hline$/ \mathrm{p} /$ & as RP & /ІІа/ & /i: a/ or /i:r/ \\
\hline /0:/ & as RP & /eə/ & / eI r/ \\
\hline / / / & as $\mathrm{RP}$ & /৩ə/ & /u: ə/ or /u:r/ \\
\hline /u:/ & as RP & word stress & as RP \\
\hline$/ \Lambda /$ & /a/ & Rhythm & as RP \\
\hline /3:/ & $/ 3: r /$ & Intonation & as RP \\
\hline$/ 2 /$ & as RP & Elision & Ignored \\
\hline$/ \mathrm{y} /$ & /ng/ & assimilation & Ignored \\
\hline $\mathrm{R}$ & {$[\mathrm{r}]$} & & \\
\hline $\mathrm{L}$ & always clear & & \\
\hline$/ 1, \mathrm{n} /$ & /əl//ən/ & & \\
\hline $\mathrm{td}$ & {$[\mathrm{t}, \mathrm{d}]$} & & \\
\hline
\end{tabular}

The current investigation analyzes Iraqi school pupils' speech based on Brown's (1988) FL principle. The choice for this model rather than the other two by Gimson (2001) and Jenkins (2000) is made for the following reasons. First, the model based on the FL does not attempt to include in its inventory pronunciation features from other nonnative English varieties or other native English accents. It was mainly based on the two main varieties of RP and GA. This goes in line with all the English language textbooks prescribed in Iraq which follow both varieties, chiefly RP. The models suggested by Gimson (2001) and Jenkins (2000) aimed at acquiring international validity. In this respect, Gimson initiated 
his model to include those pronunciation features which cover all native English accents and whose mastery will ensure native and nonnative successful communication. In contrast, Jenkins' model was chiefly proposed to include nonnative English varieties. The main aim was to propose a Linga Franca Core for international communication among nonnative English speakers in the expanding circle of English. Meeting the pronunciation goals set in Iraq, Brown's model was to achieve successful communication between nonnative and native English speaker with the implied assumption that mastering these priorities will result in intra-national and international communication success.

\section{METHOD}

This investigation follows the qualitative methodology whereby the speech data are based on a deliberately chosen reading passage read by 15 Iraqi intermediate school pupils/ Alrisafah-3. The reading passage was entitled "The Boy who Cried Wolf"(Deterding, 2006) It was selected on the basis of two main criteria. The first criterion is that it included all the phonemes of RP English. The second criterion was the avoidance of other lexical and grammatical factors which might influence pronunciation (Hardman, 2010, p.142). The reading passage is given in appendix (1). A word transcription task was used to identify the deviant pronunciation features from the RP sound system. In this respect, the researcher listened carefully to the recordings and wrote down each deviant pronunciation which was later compared with Brown's (1988) list to determine their importance. In support of the word transcription task, Moyer (2013, p.93) mentioned that it enabled the researcher to notice "the extent to which a word or utterance is recognised at the level of finer acoustic-phonetic detail."

$$
\text { Following a qualitative }
$$
methodology in the present investigation implies two things: data saturation and small sample. The researcher first chose 30 participants randomly from second year intermediate pupils. When analysing the data and identifying the pronunciation errors, the researcher found out that participant 16, 17 and 18 repeated the same pronunciation errors. Hence, the researcher decided to stop listening to other recordings and satisfied with the first 15 pupils. In education research, this is 
referred to as data saturation and it was adopted in the present investigation.

\section{RESULTS AND DISCUSSION}

This article aims at identifying and prioritizing the phonemic deviations found in the speech of the Iraqi second year intermediate school pupils to compensate for the shortcoming of English textbooks in relation to pronunciation content and practice. This is done by identifying pronunciation errors of high phonemic content. To identify these segmental phonemic load errors, the researcher transcribed and compared the speakers' original words with the researcher's orthographic transcription of these words. The analysis is based on the segmental features of RP and their phonemic value as determined by Brown's (1988) FL. The segmental deviations and their hierarchies are presented in table (4).

\section{Table (4): Phoneme Conflations and Functional Loads}

\begin{tabular}{|c|c|c|c|}
\hline $\begin{array}{l}\text { RP } \\
\text { phonemes }\end{array}$ & $\begin{array}{l}\text { Conflated } \\
\text { with }\end{array}$ & FL/ Rank & Explanations with Examples \\
\hline$/ \mathrm{p} /$ & $/ \Lambda /$ & High/10 & $\begin{array}{l}\text { Description. } \\
\text { /v/ close, back, rounded and short vowel. } \\
\text { / } \mathbf{N} \text { half close, central, short and unrounded. } \\
\text { /p/ bilabial, stop and voiceless consonant. } \\
\text { /b/ bilabial, stop and voiced consonant. } \\
\text { Functional Load. When compared to Brown's (1988) model, the } \\
\text { phonemic conflations of the above sounds are of high communicative } \\
\text { load, ranked 10. They can distinguish many English words. Thus, they } \\
\text { are prioritized for teaching purposes. } \\
\text { Examples. The conflations are observed in words like 'was', 'once' and } \\
\text { 'plan'. }\end{array}$ \\
\hline /eI / & $\mathrm{e}$ & High /9 & $\begin{array}{l}\text { Description. } \\
\text { /I/ close, front, short, unrounded. } \\
\text { /ei/ a diphthong which glides from one vowel to another. } \\
\text { le/ between half close and half open, front, short and unrounded. } \\
\text { Functional Load. When compared to Brown's (1988) model, the } \\
\text { phonemic conflations of the above sounds are of high communicative } \\
\text { load, ranked 9. They can distinguish many English words. Thus, they } \\
\text { are prioritized for teaching purposes. } \\
\text { Examples. The conflations are found in words like 'fist', 'escaped' and } \\
\text { 'late'. }\end{array}$ \\
\hline $\begin{array}{l}\text { / 3: / } \\
\text { /ou/ }\end{array}$ & / o: / & High /6 & $\begin{array}{l}\text { Description. } \\
\text { /3:/ between half close and half open, central, long, unrounded. } \\
\text { /əu/ a diphthong which glides from one vowel to another. } \\
\text { / } \mathrm{s} / \text { between half close and half open, back, long and rounded. }\end{array}$ \\
\hline
\end{tabular}




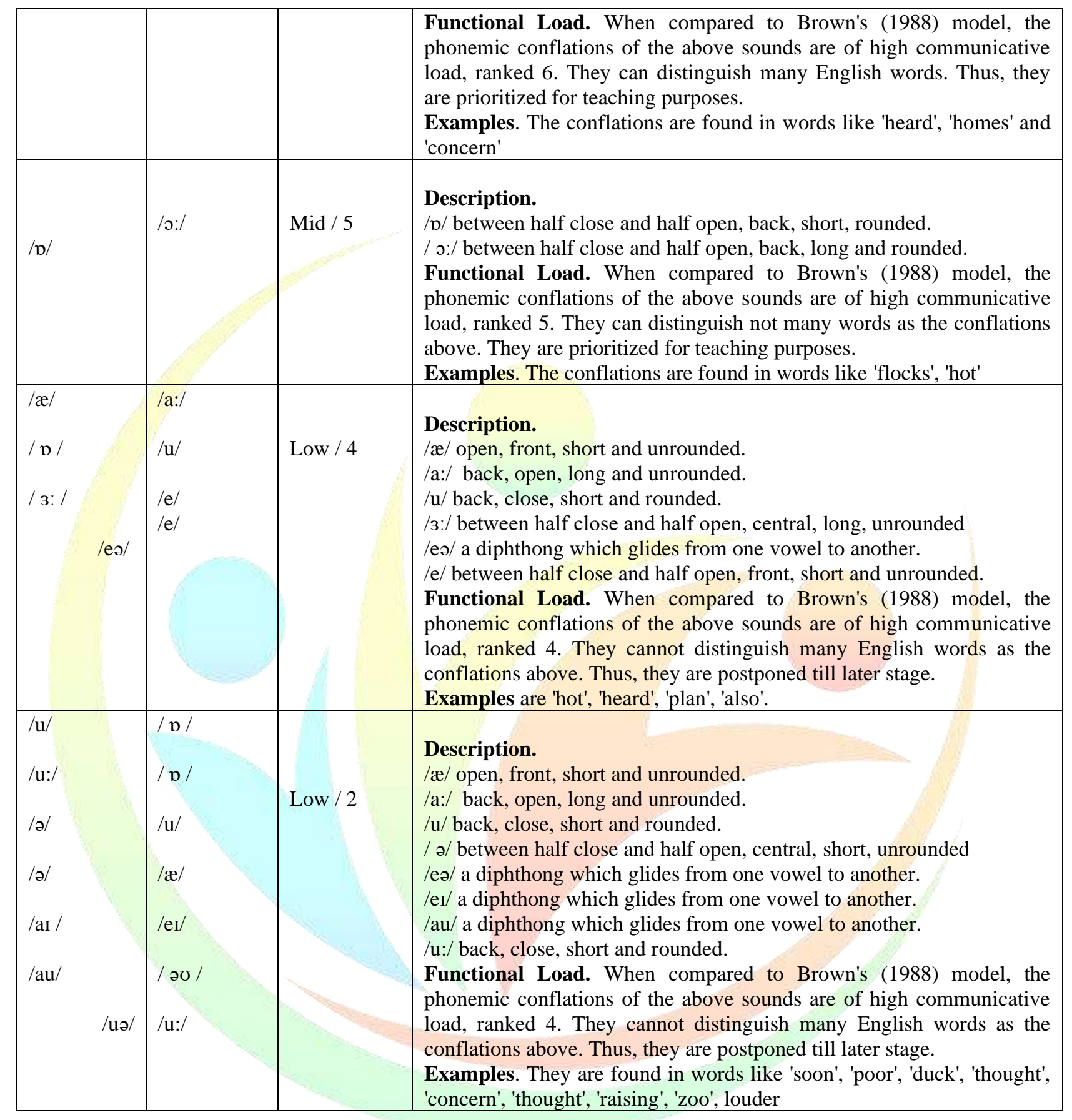

The qualitative results of this article are discussed in relation to communication, pedagogy and the nature of the results arrived. As far as communication is concerned, these results address the main purpose behind learning a language, namely communication. The results were arrived at using a communicatively based principle, the functional load principle. Hence, the importance of the identified results, the phonemic contrasts, is not their difficulty 
level based on frequency, bit it is their communicative importance in distinguishing many lexical items. From a pedagogical perspective, the results fill in a pedagogical gap manifested in the shortcomings of the existing English textbooks for Iraqi schools. The results presented can be incorporated into these textbooks and taught by the CLT. With regards to the nature of the results arrived at, the present qualitative results are in sharp contrast to those arrived at by previous pronunciation studies conducted in the Iraqi EFL context. Previous results of pronunciation research were based on either contrastive analysis or error analysis approaches. They were determined on the basis of frequency of occurrence or the absence of phonemic contrast in one of the contrasting languages. The idea that phonemes should be identified based on the number of words they can distinguish was absent.

\section{CONCLUSIONS}

The motive for carrying out the present investigation was to identify priorities in pronunciation which can compensate the shortcomings found in the English textbooks in Iraqi schools. For this aim, a qualitative methodology was adopted and the analysis of the pupils' recordings revealed a set of high and low FL pronunciation features which could be implemented in the existing English textbooks for Iraqi schools as for pronunciation content and practice. The qualitative results are discussed in relation to communication, pedagogy and the nature of the phonemic conflations arrived at. The identification of such phonemic contrasts was in line with the CLT which the teaching method used in the textbooks and recommended by the Ministry of Education in Iraq. The results of the present investigation are in sharp contrast to previous pronunciation studies conducted in Iraq regarding pronunciation. These studies focused on identifying pronunciation features on either contrastive or error analysis approaches. The findings of such approaches do not contribute to communication success as they were mainly based on frequency counts rather than phonemic loads.

\section{APPENDICES}

Appendix (1). The Reading Passage (Deterding, 2006)

\section{The Boy Who Cried Wolf}

There was once a poor shepherd boy who used to watch his flocks in the fields next to a dark forest near the foot of a mountain. One hot afternoon, he thought 
up a good plan to get some company for himself and also have a little fun. Raising his fist in the air, he ran down to the village shouting "Wolf, Wolf." As soon as they heard him, the villagers all rushed from their homes, full of concern for his safety, and two of his cousins even stayed with him for a short while. This gave the boy so much pleasure that a few days later he tried exactly the same trick again, and once more he was successful. However, not long after, a wolf that had just escaped from the zoo was looking for a change from its usual diet of chicken and duck. So, overcoming its fear of being shot, it actually did come out from the forest and began to threaten the sheep. Racing down to the village, the boy of course cried out even louder than before. Unfortunately, as all the villagers were convinced that he was trying to fool them a third time, they told him, "Go away and don't bother us again." And so the wolf had a feast.

\section{REFERENCES}

1. Abercrombie, D. (1949). Teaching pronunciation. ELT Journal, 3(5), pp.113-122.

2. Abdul-Kareem, N. T. (2009). A survey study of the syllabuses of English used in Iraq (1873-2003 AD). Diala Journal, 34, pp.1-14

3. Abid, R. A. S. (2012). Investigating EFL Iraqi learners' beliefs about learning English as a foreign language. $A D A B A L-B A S R A H,(60), \mathrm{pp} .46-81$.

4. Altufaili, I.R. (2016). Education Policy and Practices of English as a Foreign Language (EFL) in Iraq. MA thesis, Missouri State University, USA.

5. Amin, M. Y. M. (2017). English Language Teaching Methods and Reforms in English Curriculum in Iraq: An Overview. Journal of University of Human Development, pp.578-583.

6. Brown, A. (1988). Functional load and the teaching of pronunciation. TESOL Quarterly, 22(4), pp.593-606.

7. Burgess, J., \& Spencer, S. (2000). Phonology and pronunciation in integrated language teaching and teacher education. System, 28(2), pp.191-215. 
8. Crystal, D. (2008). A Dictionary of Linguistics and Phonetics (The Language Library). John Wiley \& Sons Incorporated.

9. de Bot, K., Lowie, W. and Verspoor, M. (2005). Second Language Acquisition: An Advanced Resource Book. London: Routledge.

10. Deterding, D. (2006). The North Wind versus a Wolf: short texts for the description and measurement of English pronunciation. Journal of the International Phonetic Association, 36(2), pp.187-196.

11. Hardman, J.B. (2010). The Intelligibility of Chinese-Accented English to International and American Students at a US University. PhD thesis, The Ohio State University, USA.

12. Gilner, L., \& Morales, F. (2010). Functional load: transcription and analysis of the 10,000 most frequent words in spoken English. The Buckingham Journal of Language and Linguistics, 3, pp.135-162.

13. Jenkins, J. (2006). English pronunciation and second language speaker identity. The sociolinguistics of identity, pp.75-91.

14. Levis, J. M. (2018). Intelligibility, oral communication, and the teaching of pronunciation. Cambridge: Cambridge University Press.

15. Moyer, A. (2013). Foreign Accent: The Phenomenon of Non-native Speech. Cambridge: Cambridge University Press.

16. Nunan, D. (2003). Practical English. Language Teaching. New York: Mc Graw Hill.

17. Zoghbor, W.S.K. (2011). The Effectiveness of the Lingua Franca Core (LFC) in Improving the Perceived Intelligibility and Perceived Comprehensibility of Arab Learners at Post-Secondary Level. PhD thesis, University of Leicester, UK. 